\title{
CARLOS CONTRERA
}

Este trabajo documental se realizó durante los diez años en que se llevó a cabo la restauración del Teatro Solís.

La persistencia y la regularidad en la cobertura dejaron como resultado una enorme cantidad de materiales fotográficos sobre los cuales realicé una edición. Como documentalista edito siempre pensando en el posible lector o espectador: a él está dirigida toda mi atención.

En estas fotografías muestro aquello que el lector no vio ni verá. Desde la delicadeza de la restauración del plafón de la sala a lo monumental de las estructuras de la caja escénica, con un elemento que las une: el hombre, realizador de toda la obra.

Carlos Contrera, 1954, Cerro Chato.

La foto de tapa, de este número de dixit, también forma parte del trabajo que Carlos Contrera presenta en Reflejos. 

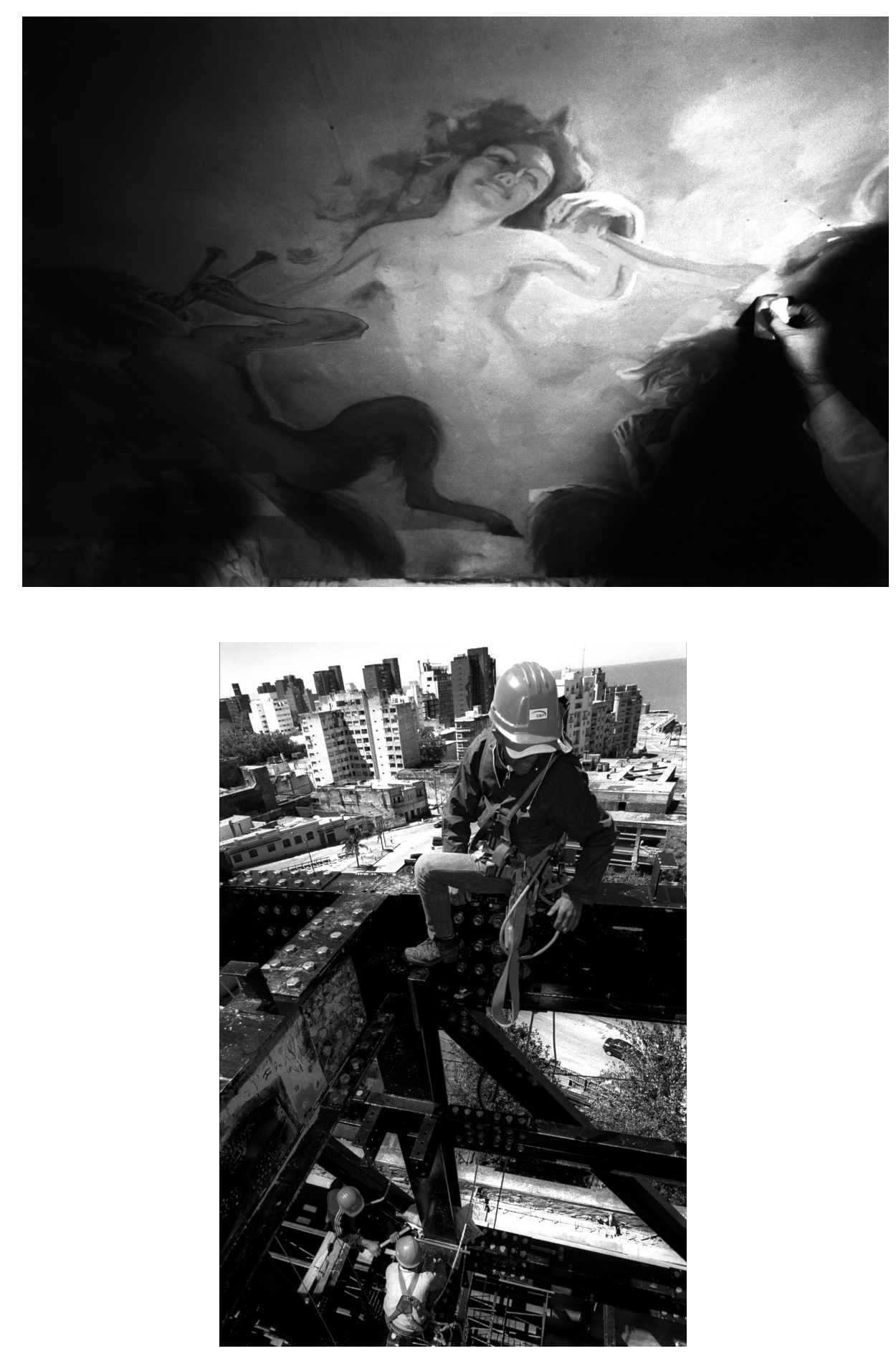


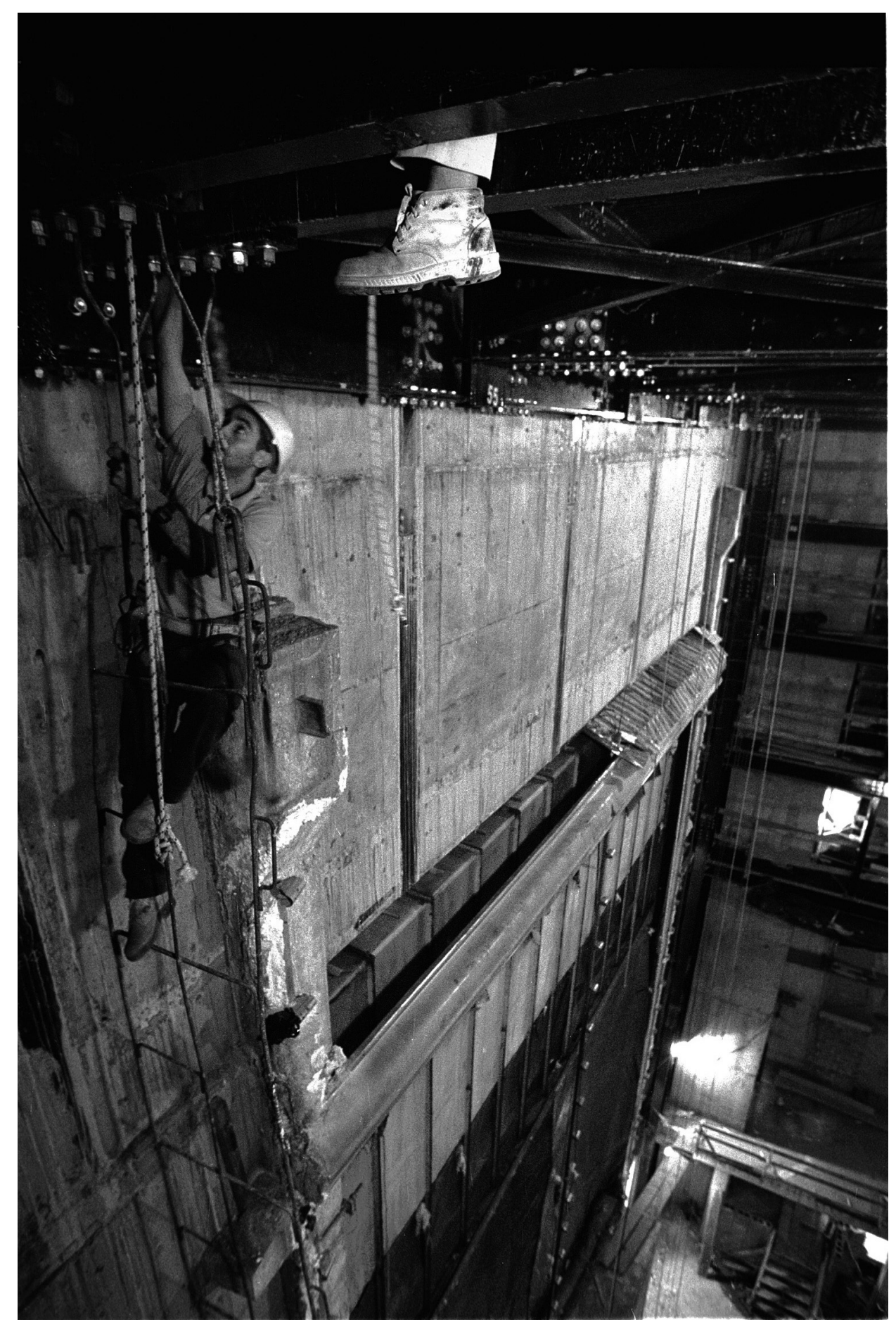

revista de comunicación :: dixit 13 